Inesa Paulava, $\mathrm{PhD}$ in Engineering Science, Associate Professor, Department of Concrete Technology and Building Materials, Brest State Technical University (Brest, Belarus)

Krystsina Belamesava, Postgraduate, Master in Engineering Science, Department of Concrete Technology and Building Materials, Brest State Technical University (Brest, Belarus)

\title{
DEPENDENCE OF CONCRETE STRENGTH ON DIFFERENT METHODS OF BASALT FIBER ADDICTING
}

(C) РУП “Институт БеАНИИС", 2019

Institute BeINIIS RUE, 2019

\section{ABSTRACT}

The present paper considers the influence of basalt fiber method of addicting in to self-stressing concrete, modified by sulfoaluminate type expansive additive, on main properties of concrete. The use of basalt fiber and expansive additive together allows to obtain a composite with optimal structure and high-quality properties. The combined application allows to achieve several effects such as filling effect, pozzolanic effect and dispersed reinforcement effect (due to chaotic fiber distribution in the concrete composite structure and needle-shaped crystal of ettringite micro reinforcement).

Use of even small amount of basalt fiber due to disintegration on a great amount of monofilaments with a great specific surface leads to an increase in concrete composite tensile strength due to spatial dispersed reinforcement effect and changing fracture toughness There is also an effect of simultaneous expansion due to adding an expansive additive and strengthening achieved by binding effect of basalt fiber as a dispersion-reinforcing element.

The maximum amount of basalt fiber in the research is limited by 4\% to prevent full percolation effect, but at the same time to provide the formation of filament spatial skeleton in the concrete structure. In this study are considered the changes of properties of the concrete composite 
with different degrees of expansion and self-stressing (varied by energyactivity and amount of sulfoaluminate expansive additive).

In the article the most optimal basalt fiber addicting method in the concrete mix is proposed, preferences and influence degree of this method on strength properties are determined.

The integral use of the modifying expansive agent makes it possible to predict an increase in impermeability due to chemical-mechanical reinforcement of the structure, which results in durability of this type of concrete. This predetermines a perspective range of their applications in various kinds of structures including those with high serviceability.

Keywords: self-stressing concrete, sulfoaluminate type expansive additive, monofilament, strength properties, suspension, linear expansion.

For citation: Paulava I., Belamesava K. Dependence of concrete strength on different methods of basalt fiber addicting. Contemporary Issues of Concrete and Reinforced Concrete: Collected Research Papers. Minsk. Institute BelNIIS. Vol. 11. 2019. pp. 63-75. https://doi. org/10.35579/2076-6033-2019-11-05

Павлова Инесса Павловна, канА. техн. наук, Аоцент, Аоцент кафедры технологии бетона и строительных материалов, Брестский государственный технический университет (г. Брест, Беларусь)

Беломесова Кристина Юрьевна, аспирант, магистр техн. наук, Брестский государственный технический университет (г. Брест, Беларусь)

\section{ЗАВИСИМОСТЬ ПРОЧНОСТИ БЕТОНА ОТ МЕТОАА ВВЕАЕНИЯ БАЗАЛЬТОВОЙ ФИБРЫ}

\section{АННОТАЦИЯ}

В статье рассмотрено влияние способа введения базальтовой фибры в напрягающий бетон, модифицированный расширяющейся добавкой сульфоалюминатного типа, на основные свойства. Совместное введение расширяющейся добавки и базальтовой фибры позволяет реализовать ряд эффектов: эффект наполнения, 
пуццолановый и эффект дисперсного армирования (как благодаря равномерному распределению фибры в теле композита, так и благодаря микроармированию игольчатыми кристаллами эттрингита при реализации механизма расширения).

Введение базальтовой фибры даже в небольших количествах благодаря распаду на огромное количество монофиламентов с высокой удельной поверхностью приводит $к$ повышению прочности бетонного композита за счет эффекта пространственного дисперсного армирования структуры и изменения вязкости разрушения. При этом также реализуется эффект одновременного расширения благодаря введению расширяющейся добавки и упрочнения из-за связывающего эффекта базальтовой фибры как дисперсного упрочняющего элемента.

Максимальное содержание базальтовой фибры в данных исследованиях ограничено $4 \%$, исходя из предпосылок предотвращения эффекта полной перколяции, но при этом обеспечения формирования условного «пространственного каркаса» из волокон фибры. В данной работе рассмотрено изменение свойств бетонного композита при разных уровнях расширения и самонапряжения (варьируется энергоактивностью и количеством вводимой сульфоалюминатной добавки). Также предложен наиболее оптимальный способ введения базальтового волокна в бетонную смесь, определены его преимущества и степень влияния на прочностные характеристики композита.

Комплексное использование модифицирующей расширяющейся добавки и базальтовой фибры позволяет спрогнозировать за счет химико-механического объемного армирования структуры повышение непроницаемости и, как следствие, долговечности такого рода бетонов, что предопределяет перспективы их применения для ремонта различного рода зданий и сооружений, в том числе эксплуатируемых в различных агрессивных средах.

Ключевые слова: напрягающий бетон, расширяющаяся добавка сульфоалюминатного типа, монофиламент, прочностные показатели, суспензия, линейное расширение. 
Для цитирования: Павлова, И. П. Зависимость прочности бетона от метода введения базальтовой фибры / И. П. Павлова, К. Ю. Беломесова // Проблемы современного бетона и железобетона : сб. науч. тр. / Ин-т БелНИИС; редкол.: О. Н. Лешкевич [и др.]. Минск, 2019. - Вып. 11. - С. 63-75. https://doi.org/10.35579/20766033-2019-11-05

\section{INTRODUCTION}

Building of modern constructions and structures needs to employ concretes with high field performance and physical-mechanical properties. One of the more actual materials on the present-day is fiber concrete - concrete with dispersed filaments (fiber).

Fiber concrete is one of the most perspective composites in the area of high performance (HPC) and high strength concretes, because they enjoy not only high strength level, but also fracture toughness, water permeability, frost resistance and durability scores of times these characteristics for ordinary concrete. But, in spite of quite of a number advantages of fiber concrete over ordinary concrete, fiber concrete is not prevailing as opposed to ordinary concrete.

It's connected with a great amount of questions that a researcher faces in the current area. Many of them are not studied to the end so there are not unambiguous answers to them.

The list of main issues which the researcher encountered to prepare fiber concrete is the following: fiber filament optimal type, its amount, method of addicting, also determining the character and the degree of influence of fiber on main properties of concrete composite structure (strength, fracture toughness, shrinkage strains, etc.).

Such for a choice of materials, used for dispersed reinforcement, they are a different types of metallic and non-metallic filaments of organic and non-organic origin. Today more popular are steel, glass, basalt, polypropylene and so on.

Each kind of fiber holds its own advantages and disadvantages. Filaments of a various origin in a different way interacting with cementitious matrix in the concrete. In tabl. 1 are presented main characteristics of commonly used dispersed reinforcement filaments. 


\section{Main characteristics of different kind dispersed reinforcement according to [1]}

\begin{tabular}{|c|c|c|c|c|}
\hline Material & Basalt fiber & $\begin{array}{c}\text { Polypropylen } \\
\text { Fiber }\end{array}$ & $\begin{array}{c}\text { Glass fiber, } \\
\text { mark E or S }\end{array}$ & Steel fiber \\
\hline Tensile strength, MPa & $1900-3900$ & $150-600$ & $1500-3500$ & $600-1500$ \\
\hline Modulus of elasticity, GPa & $90-130$ & 35 & 75 & 190 \\
\hline $\begin{array}{c}\text { Coefficient of expansion, } \\
\%\end{array}$ & 3,2 & $20-150$ & 4,5 & $3-4$ \\
\hline Melting point, ${ }^{\circ} \mathrm{C}$ & 1450 & 160 & 860 & 1550 \\
\hline Density, g/cm3 & 2,60 & 0,91 & 2,60 & 7,80 \\
\hline
\end{tabular}

Among the multitude of used dispersed reinforcement materials its necessary separately assign basalt fiber [2, p. 75].

Basalt fiber due to its mineralogical origin possess many advantages such as high level of physical-mechanical and chemical properties, durability, stability of characteristics during continuous service in a different conditions including corrosion risks, good adhesion with cement stone, high structural, heat-insulating, dielectric properties.

Basalt fiber like a dispersed reinforcement makes it possible to improve in cementitious concrete one of the major imperfections - law tensile strength. But concretes on the basis of ordinary Portland cement nonetheless on dispersed reinforcement of structure are varying shrinkage strains. In present study for compensating shrinkage strains expansive modified binders are used [3, p. 102].

To prevent shrinkage strains used a mix of ordinary Portland cement and expansive additive. Variations in amount and type of used expansive agent make it possible to obtain concretes with different levels of linear expansive strains and self-stresses. In current research is used sulfoaluminate expansive additive. Expansion mechanism is based on needle-shaped crystal ettringite formation (see figure 1) on the next type chemical reaction:

$$
\begin{gathered}
3 \mathrm{CaO} \cdot \mathrm{Al}_{2} \mathrm{O}_{3} \cdot 6 \mathrm{H}_{2} \mathrm{O}+3\left(\mathrm{CaSO}_{4} \cdot 2 \mathrm{H}_{2} \mathrm{O}\right)+19 \mathrm{H}_{2} \mathrm{O}= \\
=3 \mathrm{CaO} \cdot \mathrm{Al}_{2} \mathrm{O}_{3} \cdot 3 \mathrm{CaSO}_{4} \cdot 31 \mathrm{H}_{2} 0 .
\end{gathered}
$$




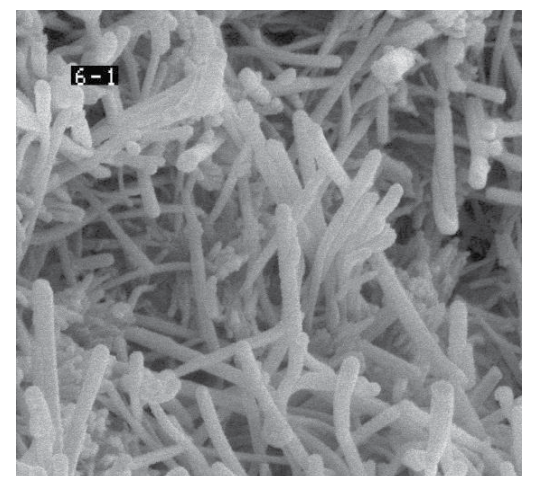

Figure 1. Needle-shaped ettringite crystals in an hydrating expansive cement structure

Integral addicting of basalt fiber with expansive additive leads to the advantageous stress-strain relationships in structure owing to chemical prestress and spatial reinforcement effects in hydrating cement system.

As can be seen from figure 2 the addicting of basalt fiber does not lead to a sharp decline in linear expansion. It allows maintaining the required level of energy activity and linear expansion. At the same time, the binding of a hydrating system to a spatial skeleton will prevent partial decompaction and strength decreases taking place in energy-active mixes.

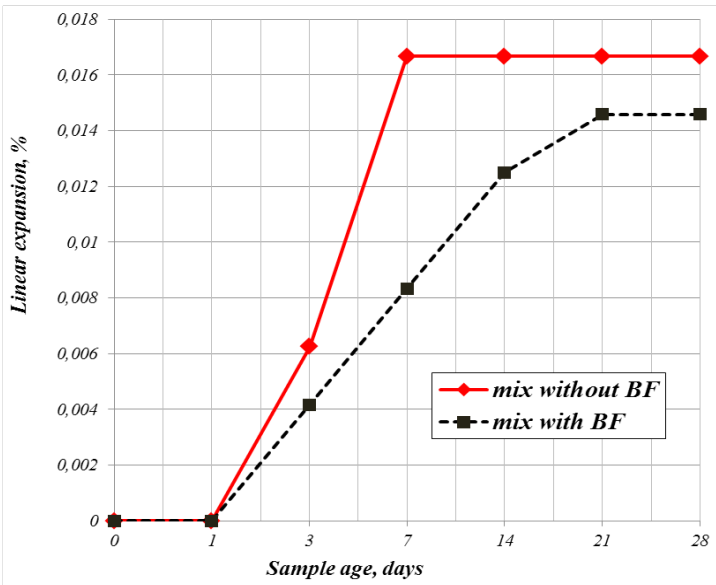

Figure 2. Development of linear expansion in time BF - basalt fiber 
There are some quite difficult moments, which researcher had to face during the concrete mix preparation. One of these moments is dispersed filament addicting in the concrete mix.

Basalt fiber, produced by cutting from roving segments of a given length, consisting of a set of parallel laid elementary fibers, assembled by sizing in temporary bundles (see figure 3 , a)

Depending on the technology of basalt fiber production in one such segment of basalt fiber («time bundle») there can be from 400 to 800 pieces of individual monofilaments. Diameter of monofilament depends from the technical characteristics of the spinneret feeder, through which the elementary fibers are drawn. When basalt fibers are combined with components of the concrete mix during mixing these temporary bundles break up into separate monofilaments. They are freely and randomly distributed throughout the entire volume of the composite causing special reinforcement effect. Homogeneous fiber distribution in the cement composite structure leads to a forming of spatial micro-reinforced cement matrix (see figure 3, b). This type of structure effectively counteracts the compressive and tensile stresses that occur in concrete under external force effects.
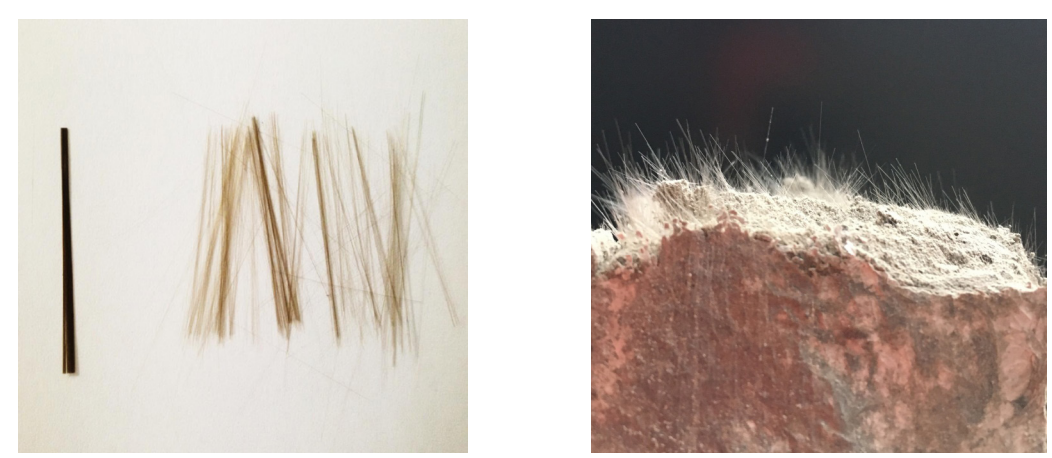

Figure 3. Type of basalt monofilament (a) and fiber-reinforced concrete samples after tensile strength test $(b)$

One of the main tasks to achieve a uniform distribution of fiber in the body of concrete composite is to determine the optimal method of addicting and mixing basalt fiber with the components of concrete mix. 
Moreover, the uniform distribution of basalt fiber in the concrete composite structure is influenced by a number of complicated technological aspects, including water to binder ratio, usage of high efficiency plasticizing admixtures, quality of the used raw materials such as chemical-mineralogical cement composition and its specific surface, continuous grading for aggregates and so on.

There is no well-substantiated method of addicting basalt fiber into the concrete mix, which will allow achieving uniform fiber distribution throughout the entire volume of the concrete mix.

Results of the search of optimal method of addicting are presented in several studies [1, 4-6]. It can be selected next basic methods: - fiber is addicting into the dry components of the mix; - fiber is addicting in cement suspension; - fiber is addicting in the already prepared mix.

\section{EXPERIMENTAL STUDIES}

The common purpose of this study is determining of the optimal method of addicting basalt fiber into a concrete mix, which allows achieving the most homogeneous distribution of fibers in the structure of concrete composite.

In present studies the following methods were chosen: - fiber is addicting to dry components (Scheme 1 ) and - fiber is addicting to the cement suspension (Scheme 2).

Self-stressing cement consisting of a mix of ordinary Portland cement and an expansive additive was used as a binder. Expansive additive prepared as a mixture of highly active metakaolin $\mathrm{Al}_{2} \mathrm{O}_{3} 2 \mathrm{SiO}_{2}$ with high pozzolanic reactivity $(1200 \mathrm{mg} / \mathrm{g})$ and natural gypsum $\mathrm{CaSO}_{4} 2 \mathrm{H}_{2} \mathrm{O}$ in proportion 0,9:1. Amount of expansive agent in binder is chosen $15 \%$ proceeding from expansive strains achievement (see figure 2 - mix without basalt fiber). Studied mixes, quantity of control samples and its shape and size, also control of expansive/shrinkage strains are realized according to STB 1335 [7] requirements: the ratio of cement to sand was taken to be $1: 3$; water to binder ratio 0,4 ; the content of basalt fiber was taken to be $4 \%$ by weight of the binder. In this study were prepared standard samples-prisms $4040160 \mathrm{~mm}$ in amount 9 per each scheme. Technical characteristics of the fiber are shown in Table 2. 
Technical characteristics of the used basalt fiber

\begin{tabular}{|c|c|}
\hline Name of the indicator & Value \\
\hline Basalt fiber length, mm & 24,5 \\
\hline Diameter of the individual monofilament, $\mu \mathrm{M}$ & 16 \\
\hline Modulus of Elasticity, MPa & $93200-116000$ \\
\hline Fructure strength, MPa & $1500-2000$ \\
\hline Density, g/cm3 & 2,7 \\
\hline
\end{tabular}

The use of ultrafine expansive additive (metakaolin specific surface is about $10 \times 10^{4} \mathrm{~cm}^{2} / \mathrm{g}$ ) in complex cement compound needs to use plasticizer of I group of effectiveness. Also in plasticized mixes is easier to achieve a more uniform distribution of basalt fiber. In present study a plasticizer based on modified polycarboxylate esters was used.

According two schemes for loading materials in the preparation of fiber concrete mix (see Table 3) was used a different regularity for loading materials.

Table 3

\section{Preparation stages of basalt-fiber concrete mix according to the accepted schemes}

\begin{tabular}{|c|c|c|}
\hline \multirow{2}{*}{$\begin{array}{c}\text { No of } \\
\text { stage }\end{array}$} & Scheme 1 & Scheme 2 \\
\cline { 2 - 3 } & Mix components & Mix components \\
\hline 1 & Self-stressing cement + Sand & $\begin{array}{c}\text { Self-stressing cement + Water + Plasticizer } \\
(0,8 \%)\end{array}$ \\
\hline 2 & Basalt fiber (4\%) & Basalt fiber (4\%) \\
\hline 3 & Water + Plasticizer (0,8\%) & Sand \\
\hline
\end{tabular}

As noted earlier, this study examined two schemes for loading materials that have main differences consisting of the regularity of the addicting of basalt fiber into the concrete mix: 
scheme 1 - the addicting of basalt fiber in a dry mix of cement and sand. Obtaining a homogeneous mixture of dry components. Next subsequent mixing with water and a plasticizing admixture;

scheme 2 - the addicting of basalt fiber in a pre-prepared suspension consisting of cement, water, and plasticizer. Obtaining a homogeneous mixture. Next the subsequent addicting of sand with the joint mixing of all components in mix.

The mix without basalt fiber was taken as the control. Since one of the main advantages of dispersed reinforcement is an increase in the tensile strength of cement composites - this characteristic was chosen as control in experimental studies. Tests of control samples were made at the age of 2, 7 and 28 days. The results are presented in Figure 4.

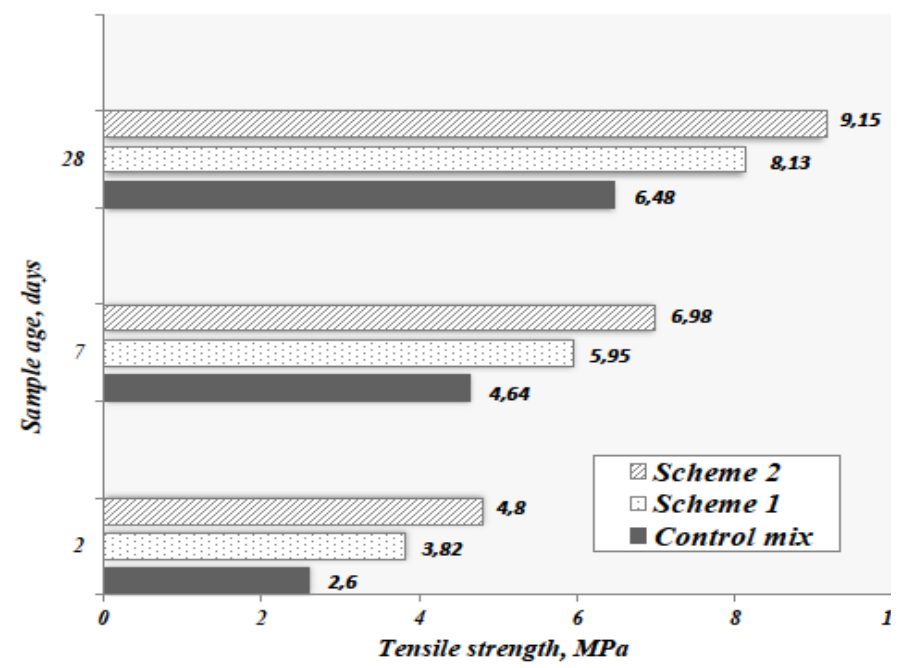

Figure 4. Dependence sample tensile strength according different schemes of fiber addicting

\section{RESULTS OF EXPERIMENTAL STUDIES AND THEIR ANALYSIS}

Analyzing the data obtained from experimental studies, it is possible to make some conclusions concerning the degree of influence of basalt fiber on the most important physical-mechanical characteristics of a 
concrete composite, and also to determine the most optimal method of the addicting of fiber into a concrete mix.

Figure 4 clearly shows that the use of basalt fiber as a dispersed reinforcement (regardless of the method of its addicting into the concrete mix) leads to increase in the tensile strength of concrete composites structures.

Basalt fiber-reinforced samples have bending tensile strength on average $25 \%$ higher than the strength values of control samples without reinforcement. The effect of strength increasing takes its maximum at an early age (for samples at the age of 2 days tensile strength increase vary from $32 \%$ to $45 \%$ ).

As for the optimal method of addicting the basalt fiber into a concrete mix - the second scheme - the addicting of basalt fiber into a cement suspension - is the most rational. The tensile strength of samples prepared using the scheme 2 exceeded about $12 \%$ compared with samples prepared according to the first scheme (with the addicting of components in a dry form).

The studied schemes for obtaining a basalt fiber concrete mix have some advantages and disadvantages. For example, with the addicting of basalt fiber in a dry mix (Scheme 1) during the mixing process, each fiber section is divided into many elementary fibers. At a sufficiently high frequency of rotation of the mixing equipment individual monofilaments are released into the air and a small proportion of the reinforcing fibers are lost. Also addicting of basalt fiber into dry components often leads to incomplete separation of fibers into individual monofilaments, which further leads to the clumping of basalt fibers. The presence of lumps of basalt fibers leads to a decrease in the strength characteristics of the concrete composite.

Addicting of basalt fiber in a suspension of cement, water and plasticizer (Scheme 2) results that mentioned above effects are not observed. The losses of reinforcing fibers and ultra dispersed expansive additive into the air on the stage of concrete mix preparation are completely excluded. This method of the addicting (Scheme 2) allows the fiber to be uniform distributed in the cement paste. However, this method is fraught with some difficulties in the technological plan, since it is not always possible to introduce raw materials in suspension in construction conditions or in-situ. 
As seen from the obtained data the addicting of the basalt fiber is more rational according to Scheme 2 (into the cement suspension). Method of the addicting fiber in suspension allows to more uniform distribution of the filaments in the concrete structure, resulting in the forming of a spatial dispersed reinforced cement matrix.

\section{CONCLUSIONS}

1. Using of basalt fiber and an expansive additive together in the hydrating cement system allows to achieve the effect of expansion without decompaction and strength decreasing [2,3], which is usually manifested in energy-active compounds. At the same time, the addicting of basalt fiber only slightly reduces the strain of free expansion, which allows that the energy potential of the modified binder to be fully realized.

2. Dispersed basalt fiber reinforcement of cement systems leads to the creation of a spatial skeleton according to the free and chaotic distribution of elementary fibers in the composite structure. This spatial skeleton allows to restrict the destructive stresses leading to the formation of through or surface cracks.

3. Usage of basalt fiber as a dispersed reinforcement (regardless of the method of its addicting into the concrete mix) leads to strength increasing of the concrete composite. Samples reinforced with basalt fiber have an average value of tensile strength $25 \%$ higher than the strength of control samples without reinforcement. The tensile strength increasing its maximum at an early age due to more impermeable microstructure with high dispersed ettringite instead incoherent structure of ordinary Portland cement with high porosity and «card house» structure of aluminate phase (the strength increasing vary from $32 \%$ to $45 \%$ ).

4. Addicting basalt fiber into the concrete mix in suspension with ultra dispersed expansive sulfo-aluminate additive allows achieving the most uniform distribution of the filaments in the modified cement matrix. In modified hydrating structure realized effects both of chemical prestress due to ettringite formation and spatial reinforcement due to basalt fiber volumetric distribution, which resulting in concrete properties increase. 


\section{REFERENCES}

1. Rabinovich F. N. Kompozity na osnove dispersno-armirovannykh betonov [Composites based on dispersion-reinforced concrete]. Voprosy teorii i proyektirovaniya, tekhnologiya, konstruktsii: Monografiya. Moscow: Izdatelstvo ASV, 2004. - 560 p. (rus)

2. Belomesova K. YU. Primeneniye bazaltovoy fibry v kachestve armiruyushchego komponenta $\mathrm{v}$ tsementno-peschanykh kompozitakh [Usage of basalt fiber such as component of reinforcement in cement-sand composites]. Traditsii, sovremennye problemy i perspektivy razvitiya stroitelstva: $s b$. nauch. st. Grodno : GrGU. 2016. pp. 74-77. (rus)

3. Pavlova I. P., Kalenyuk T. V., Belomesova K. YU. Issledovaniye vliyaniya rasshiryayushchikhsya sulfoferritnykh i sulfoalyuminatnykh dobavok na prochnostnyye pokazateli i sobstvennyye deformatsii tsementnykh sistem [Research of expansive sulfoferrite and sulfo-aluminate additives on binding cementitious systems strength properties and self-strains]. Vestnik BrGTU. 2016. No. 1. pp. 123-127. (rus)

4. Borovskikh I. V. Vysokoprochnyy tonkozernistyy bazaltofibrobeton [High-strength fine-grained basalt fiber concrete]: Dis. ... kand. tekhn. nauk: 05.23.05 / Borovskikh Igor Viktorovich. 2009. pp. 146-163. (rus)

5. Derevyanko V. N. Stoykost bazaltovogo volokna v razlichnykh sredakh [Resistance of basalt fiber in various environments]. Visnik PDABA.2010. No. 2. pp. 1-6. (rus)

6. Buchkin A. V. Melkozernistyy beton vysokoy korrozionnoy stoykosti, armirovannyy bazaltovym voloknom [Fine-grained concrete of high corrosion resistance, reinforced with basalt fiber]. Tekhnologii betonov. 2011. No. 9-10. pp. 38-40. (rus)

7. Tsement napryagayushchiy. Tekhnicheskie usloviya [Selfstressing cement. Technical conditions]. STB 1335. Introduced: 01.01.2003. Minsk: Minstroyarkhitektury, 2002. 11 p. (rus)

Received: 28.11.2019 